\title{
OVIPOSITION AND PREDATION BY Speciomerus revoili (COLEOPTERA, BRUCHIDAE) ON SEEDS OF Acrocomia aculeata (ARECACEAE) IN BRASÍLIA, DF, BRAZIL
}

\author{
RAMOS, F. A., MARTINS, I., FARIAS, J. M., SILVA, I. C. S., COSTA, D. C. and \\ MIRANDA, A. P. \\ Faculdade de Ciências da Saúde, Centro Universitário de Brasília, UniCEUB, SEPN 707/907, \\ CEP 70950-075, Brasília, DF, Brazil \\ Correspondence to: Frederico Araujo Ramos, Faculdade de Ciências da Saúde, Centro Universitário de \\ Brasília, UniCEUB, SEPN 707/907, CEP 70950-075, Brasília, DF, Brazil, e-mail: framos@ tba.com.br \\ Received June 13, 2000 - Accepted July 24, 2000 - Distributed August 31, 2001
}

\begin{abstract}
Oviposition and predation levels by Speciomerus revoili bruchid beetles were quantified on fruits and seeds of the macaúba palm, Acrocomia aculeata, collected from below mother-trees within the Sarah Kubitschek Park of Brasília, DF, Brazil. A maximum of 12 eggs per fruit were found, with high variations observed between samples. No clear pattern was found for the distribution of the number of eggs per fruit, perhaps due to the artificial conditions of the study area, the absence of dispersers and/ or the plasticity in the oviposition behavior of the insect. The number of eggs per fruit was not related to fruit size, but was associated with their availability under the tree-mother. This suggests that the density of eggs per fruit is a balance between the availability of this resource and the number of females in the beetle population. The observed mortality rate, from the egg phase to the final larval stages, was over 75\%. About $40 \%$ of the seeds of Acrocomia aculeata were predated by Speciomerus revoili.
\end{abstract}

Key words: beetle, palm, insect-plant interaction, Cerrado, urban area.

\section{RESUMO}

\section{Oviposição e predação de Speciomerus revoili (Coleoptera, Bruchidae) em sementes de Acrocomia aculeata (Arecaceae) em Brasília, DF, Brasil}

A oviposição e os níveis de predação de Speciomerus revoili foram quantificados em frutos e sementes da palmeira Acrocomia aculeata, coletados sob a árvore-mãe, no Parque Sarah Kubitschek, em Brasília, DF. Foi encontrado um máximo de 12 ovos por fruto, com grandes variações entre as amostras. Não foi encontrado um padrão muito claro na distribuição de ovos por fruto, talvez devido às condições artificiais da área de estudo, à ausência de dispersores e a uma plasticidade no comportamento de oviposição do inseto. O número de ovos por fruto não foi relacionado ao tamanho do fruto, mas à sua disponibilidade sob a árvore-mãe. Sugere-se que a densidade de ovos por fruto seja um ajuste entre a disponibilidade deste recurso e a quantidade de fêmeas na população do besouro. A taxa de mortalidade observada da fase de ovo até as larvas dos últimos estádios ficou acima de $75 \%$. Cerca de $40 \%$ das sementes de Acrocomia aculeata foram predadas por Speciomerus revoili.

Palavras-chave: besouro, palmeira, interação inseto-planta, Cerrado, área urbana. 


\section{INTRODUCTION}

Members of the beetle family Bruchidae are seed predators, which primarily attack plants from the family Leguminosae ( $84 \%$ of host plants), followed by Convolvulaceae (4.5\%), Arecaceae (4.5\%), Malvaceae (2\%) and an additional 29 other families (Johnson et al., 1995). Throughout the last three decades, this taxonomic group has been used in the construction and testing of theories about animal-plant interactions (Janzen, 1969, 1971b, 1980; Wilson \& Janzen, 1972; Johnson, 1990). The subfamily Pachymerinae is usually found predating seeds of Arecaceae (Palmae), being represented in the New World by the tribe Pachymerini. According to recent compilations (Johnson et al., 1995; Delobel et al., 1995), there are 20 beetles species, from four genera, which are known to predate the seeds of 100 palm species. For the Neotropical region, studies of Pachymerini-Arecaceae interactions have been published in Central America (Janzen, 1971a; Wilson \& Janzen, 1972; Bradford \& Smith, 1977; Wright, 1990; Forget et al., 1994). In Brazil, despite that a number studies have been made (Garcia et al., 1980; Fragoso, 1997; Link \& Naibo, 1995; Fragoso, 1997; Scariot, 1998), there are still many lacunas to be explored and, likely, species to be described. This may be verified by the void of information for Central Brazil, according to species' distribution maps (Nilsson \& Johnson, 1993).

Speciomerus revoili (Pic) belongs to a guild of bruchids which are well-known for laying their eggs on fallen seeds and mature fruits (Johnson, 1981). It uses Acrocomia aculeata (Jacq.) Lodd. former Mart., known as the macaúba, a widely distributed neotropical palm (Lorenzi et al., 1996), as its host plant. In the Distrito Federal, Brazil, fruiting individuals can be found throughout most of the year, although there is a greater concentration during the months from October to January (Scariot et al., 1991, 1995). Aspects relating to the dispersion and predation of their seeds were addressed by Scariot (1998), revealing two bruchid species: Caryobruchus acrocomiae (= Speciomerus revoili) and Pachymerus sp.

The decisive factors for oviposition and predation levels on seeds of the host have been studied. There is evidence that ovipositon patterns may be related to the size and/or availability of seeds (Wilson \& Janzen, 1972; Siemens \& Johnson, 1992; Fox
\& Mousseau, 1995; Moegenburg, 1996; Siemens \& Johnson, 1996). Other factors, such as the degree of maturity or the stage of decomposition of the fruit, may also influence infestation levels (Delobel et al., 1995). Scariot (1998) verified that fruits of Acrocomia aculeata which had been chewed by cattle, had higher indices of oviposition by bruquids, when compared to those unchewed.

The objective of this study was to describe the oviposition pattern and the levels of predation on Acrocomia aculeata by Speciomerus revoili. Specifically, we tried to answer the following questions: (a) how many eggs are laid on each fruit?; (b) are eggs laid in a random manner on the fruits?; (c) does the number of eggs on each fruit depend on the size or quantity of fruit which are available?; and (d) of the total number of fruit under the mother-tree, how many had their seeds predated?

\section{METHODS}

\section{Study area}

The palm trees here studied grow within the Sarah Kubitschek Park, in the city of Brasília, DF, forming a group of 100 palms. The area presents a typical Cerrado climate, marked by strong seasonality, with rainy summers and dry winters. Besides the palm trees, an herb-grass layer covers the soil of the entire area. Despite being close to an access road, there was no intense use of the area by people. During collection, the fruits had to be uncovered from the grass where they were hidden.

\section{Collection}

On October 4, 1997, ten Acrocomia aculeata mother-trees were randomly chosen, and fruits found below those trees were collected. To avoid samples with fruit that had fallen at different times, we tried to collect only recently-fallen fruit, with their epicarps and mesocarps still in good condition. Each fruit was inspected visually to count the number of eggs laid on its surface, and the length of the fruit was measured with a caliper. Since the larvae of Speciomerus revoili only consume seeds, a measurement of the seed would have been a more accurate estimate of resource quantity. However, since the hard, dense endocarp of Acrocomia aculeata fruit impedes the removal of the seeds without damaging them, as well as harming the development of the larvae, the size of the fruit 
was used as an estimate for the amount of resource offered by each macaúba seed. The fruits were marked and kept in glass jars for 60 days, allowing sufficient time for all of the eggs to hatch and the first adults to emerge. Finally, all of the fruits were opened and the larvae number was counted, many of which were still in development.

\section{Data analyses}

Differences between fruit sizes and differences between the number of eggs per fruit for different mother-trees were tested for through a variance analysis. To confirm whether or not the oviposition pattern was random, the eggs number per fruit was used to generate frequency distributions, which were tested against a Poisson distribution through the Chi-square test. Regression analyses were used to investigate the relationships among (a) the number of eggs laid on the surface of the fruit and the size of the fruit and (b) the number of eggs laid per fruit and the quantity of fruit under the mother-tree.

\section{RESULTS}

The data regarding fruit size, oviposition and predation levels of Speciomerus revoili on Acrocomia aculeata in Sarah Kubitschek Park are presented in Table 1. The length of the macaúba fruits varied from 2.9 to $4.2 \mathrm{~cm}$, presenting significant difference between the sizes of fruit produced in different palm trees $(\mathrm{F}=33.8, \mathrm{p}<0.001)$.

Up to 12 bruchid eggs were found on the same fruit, and the average number of eggs per fruit varied between palm trees $(\mathrm{F}=3.9, \mathrm{p}<0.001)$. Despite this, on many fruits $(8.1 \%$ to $48.8 \%)$ no eggs were found (Table 1). When the distribution of the eggs number per fruit was compared with a Poisson distribution, no clear pattern was observed for the oviposition of this bruchid. In three samples, oviposition was random, while in the seven remaining samples the pattern tended toward an aggregation of eggs.

The eggs number per fruit was not significantly correlated to fruit size, suggesting that females do not discriminate fruit by size, when laying their eggs. However, there was a weak negative relationship between the average number of eggs per fruit and the number of fruits below each bunch $\left(\mathrm{r}^{2}=\right.$ $0.31, F=5.14, p<0.05)$, suggesting that when the availability of fruit under the mother-tree increases, females decrease the density of eggs per fruit.

The quantity of fruits predated was much less than the quantity of fruits which had eggs laid on them, indicating a high mortality of eggs or of the early stage larvae (Table 1). From a total of 649 eggs, only $120(18.5 \%)$ reached the final larval stages. In only two of the fruits having two seeds were two larvae found alive, one larva per seed.

TABLE 1

Fruit size, oviposition, predation level and mortality of Speciomerus revoili on Acrocomia aculeata in the Sarah Kubitschek Park in Brasília, DF, Brazil.

\begin{tabular}{|c|c|c|c|c|c|c|c|}
\hline $\begin{array}{c}\text { Mother- } \\
\text { tree }\end{array}$ & $\begin{array}{c}\text { Number of fruits } \\
\text { collected (n) }\end{array}$ & $\begin{array}{c}\text { Average fruit } \\
\text { length (cm) }\end{array}$ & \multicolumn{2}{|c|}{$\begin{array}{c}\text { Average number of } \\
\text { eggs per fruit }\end{array}$} & $\begin{array}{c}\text { Fruit without } \\
\text { eggs (\%) }\end{array}$ & $\begin{array}{c}\text { Fruit predated } \\
(\%)\end{array}$ & $\begin{array}{c}\text { Mortality egg- } \\
\text { larva (\%) }\end{array}$ \\
\hline A & 22 & 3.68 & 3.27 & ${ }^{* *}$ & 13.6 & 50.0 & 84.7 \\
\hline B & 32 & 3.51 & 1.09 & $*$ & 46.9 & 21.9 & 80.0 \\
\hline C & 37 & 3.66 & 2.70 & Ns & 8.1 & 62.9 & 77.0 \\
\hline D & 22 & 3.23 & 2.86 & $* *$ & 13.6 & 68.1 & 76.2 \\
\hline E & 33 & 3.45 & 2.21 & NS & 9.9 & 30.3 & 86.3 \\
\hline F & 34 & 3.70 & 2.62 & $* *$ & 23.5 & 48.5 & 80.9 \\
\hline G & 16 & 3.49 & 2.75 & $* *$ & 31.2 & 35.3 & 86.4 \\
\hline H & 43 & 3.50 & 1.07 & $* *$ & 48.8 & 25.6 & 76.1 \\
\hline I & 35 & 3.67 & 2.06 & NS & 20.0 & 22.9 & 88.9 \\
\hline J & 24 & 3.90 & 2.29 & $*$ & 20.8 & 43.5 & 81.8 \\
\hline Totals & 298 & 3.58 & 2.18 & & 24.5 & 39.6 & 81.4 \\
\hline
\end{tabular}

${ }^{\mathrm{a}}$ Chi-square; $* \mathrm{p}<0.05 ; * * \mathrm{p}<0.01$; and NS not significant. 
On average, $39.6 \%$ of the A. aculeata seeds were predated by the bruchids, with infestation levels of the samples varying from $21.9 \%$ to $68.1 \%$. There was no significant difference between the sizes of the predated and non-predated fruits $(\mathrm{t}=$ $0.37, \mathrm{p}>0.7)$.

\section{DISCUSSION}

The distribution of eggs per fruit tended toward an aggregation of eggs, despite not presenting a very clear pattern. This situation may be reflecting the artificial conditions of the study area - an urban park, with potential dispersers being limited to small mammals and humans. The absence of dispersers may increase the local availability of oviposition sites for the females, bringing about an increase in the density of eggs per fruit and consequently the effects of density dependence (Siemens \& Johnson, 1996). Another factor to be considered is that dispersal agents, by removing the pulp of the fruit, may promote an increase of oviposition levels by female bruchids on the endocarp, as observed for Acrocomia aculeata (Scariot, 1998), Scheelea zonensis (Wright, 1990) and S. rostrata (Janzen, 1971a). In an inverse situation, a decrease in infestation may be observed when dispersers remove seeds to locations outside of the bruchid infestation area, or, when manipulating the fruit, they remove the bruchid eggs or larvae which are still in the pulp (Fragoso, 1997). The absence of well-defined oviposition patterns for bruchids suggests high behavioral plasticity by these insects, which adjust the optimal number of eggs laid per seed to different environmental conditions (Siemens \& Johnson, 1996).

Within the context of maximizing fitness, females of some bruchid species may adjust the number of eggs they lay on a particular seed in response to its size. Hence, the females lay a greater quantity of eggs on larger seeds, which contain more resources for the development of their larvae (Fox \& Mosseau, 1995; Moegenburg, 1996). Our data showed that the density of eggs per fruit was not dependent upon the size of the Acrocomia aculeata fruit, suggesting that females of Speciomerus revoili do not select larger fruits for oviposition. The size of the seed does not always present a linear relationship with the density of bruchid eggs. The size of Enterolobium cyclo- carpum seeds determines the density of Stator generalis eggs, up until an optimal size, when smaller seeds, with less eggs become preferable to large seeds with many eggs (Siemens \& Johnson, 1996). For the plant, optimal seed size would be reached through a balance between both dispersion mechanisms and escape from predators, which select for small seeds, and the vigor of the seedling, which selects for large seeds. Similar to plants of other families, a high degree of individual variation exists for the size of palm fruits, which may be considered as a strategy to meet opposing selection pressures (Moegenburg, 1996).

On the other hand, the data show that the density of eggs per fruit decreases with an increase in the quantity of fruit below each bunch. Similar patterns of oviposition and predation levels have been found in other bruchid species (Wilson \& Janzen, 1972; Siemens \& Johnson, 1992; Moegenburg, 1996). It is believed that females can discriminate between fruits with and without eggs during oviposition, choosing to oviposit on fruits without eggs, which would decrease the negative effects of density dependence, such as competition between larvae and the degree of parasitism on the eggs. As of the moment in which all fruits had one or a few eggs, females would no longer have a choice, having to oviposit a second time on those fruits (Siemens \& Johnson, 1992). The average density of eggs per fruit would be, therefore, a balance between the availability of fruits under the mother-tree and the number of females in the beetle population.

The level of predation by Speciomerus revoili over seeds of this population of Acrocomia aculeata was moderate (about 40\%), and large differences in predation levels were observed between the seeds of different mother-trees. For other palm tree species, these variations, and the levels of seed predation, are also observed for bruchids close to the mother-tree. In some cases, the predation may become extremely high (Bradford \& Smith, 1977; Garcia et al., 1980; Forget et al., 1994; Delobel et al., 1995; Link \& Naibo, 1995; Fragoso, 1997). This could negatively influence the recruitment of young individuals into the population of the host species (Huffaker et al., 1984). Besides, a possible source of error of this study, is that only recently-fallen fruits were collected, underestimating the number eggs that could have been laid posteriorly and the consequent increases in predation levels. 
High mortality rates (above 75\%) were observed from the egg phase to the final larval stages. This pattern is common for species that do not have parental care behaviors, or even for populations that suffer the negative effects of high densities, having several possible causes of mortality. Among them, Siemens \& Johnson $(1992,1996)$ mention the parasitism of eggs, embryonic death, damages caused by sampling, the unsuccessful of larvae in penetrating the seed and competition among larvae. Predation of eggs by ants, parasitoids and climatic extremes of high temperature and lower humidity are also causal factors of mortality for bruchids (Traveset, 1990, 1991).

Acknowledgments - The authors thank Aldicir Scariot and Ivone R. Diniz for discussions and revision of the manuscript, Cibele S. Ribeiro-Costa for the identification of the bruchid.

\section{REFERENCES}

BRADFORD, D. F. \& SMITH, C. C., 1977, Seed predation and seed number in Scheelea palm fruits. Ecology, 58: 667-673.

DELOBEL, A., COUTURIER, G., KAHN, F. \& NILSSON, J. A., 1995, Trophic relationships between palms and bruchids (Coleoptera: Bruchidae: Pachymerini) in Peruvian Amazonia. Amazoniana, 13(3/4): 209-219.

FORGET, P. M., MUNOZ, E. \& LEIGH, E. G., 1994, Predation by rodents and bruchid beetles on seeds of Scheelea palms on Barro Colorado Island, Panama. Biotropica, 26(4): 420-426.

FOX, C. W. \& MOUSSEAU, T. A., 1995, Determinants of clutch size and seed preference in a seed beetle, Stator beali (Coleoptera: Bruchidae). Environmental Entomology, 24(6): 1557-1561.

FRAGOSO, J. M. V., 1997, Tapir-generated seed shadows: scale-dependent patchiness in the Amazon rain forest. Journal of Ecology, 85: 519-529.

GARCiA, A. H., ROSA, J. A. M. \& COSTA, M. G. G., 1980, Contribuição ao conhecimento do ataque de Pachymerus nucleorum (Coleoptera Bruchidae) em Syagrus oleraceus (Palmae). Anais da Escola de Agronomia e Veterinária, Goiânia, 10: 5-11.

HUFFAKER, C. B., DAHLSTEN, D. L., JANZEN, D. H. \& KENNEDY, G. G., 1984, Insect influences in the regulation of plant populations and communities, pp. 659-691. In: C. B. Huffaker \& R. L. Rabb (eds.), Ecological Entomology. John Wiley \& Sons, NY.

JANZEN, D. H., 1969, Seed eaters versus seed size, number, toxicity and dispersal. Evolution, 23: 1-27.
JANZEN, D. H., 1971a, The fate of Scheelea rostrata fruits beneath the parent tree: predispersal attack by bruchids. Principes, 15: 89-101.

JANZEN, D. H., 1971b, Seed predation by animals. Annual Review of Ecology and Systematics, 2: 465-492.

JANZEN, D. H., 1980, Specificity of seed-attacking beetles in a Costa Rican deciduous forest. Journal of Ecology, 68: 929-952.

JOHNSON, C. D., 1981, Interactions between bruchid (Coleoptera) feeding guilds and behavioral patterns of pods of Leguminosae. Environmental Entomology, 10: 249-253.

JOHNSON, C. D., 1990, Coevolution of Bruchidae and their hosts: evidence, conjecture and conclusions, pp. 181-188. In: K. Fujii, A. M. R. Gatehouse, C. D. Johnson, R. Mitchel \& T. Yoshida (eds.), Bruchids and legumes: economics, ecology and coevolution. Kluwer Academic, Dordrecht, The Netherlands.

JOHNSON, C. D., ZONA, S. \& NILSSON, J. A., 1995, Bruchid beetles and palm seeds: recorded relationships. Principes, 39: 25-35.

LINK, D. \& NAIBO, J. G., 1995, Nível de infestação de Butiobruchus sp. em amêndoas de butiazeiro. Ciência Rural, 25: 201-203.

LORENZI, H., SOUZA, H. M., MEDEIROS-COSTA, J. T., CERQUEIRA, L. S. C. \& VON BEHR, N., 1996, Palmeiras no Brasil: exóticas e nativas. Ed. Plantarum, Nova Odessa, SP.

MOEGENBURG, S. M., 1996, Sabal palmetto seed size: causes of variation choices of predators, and consequences for seedlings. Oecologia (Berlim), 106(4): 539-543.

NILSSON, J. A. \& JOHNSON, C. D., 1993, A taxonomic revision of the palm bruchids (Pachymerini) and a description of the world genera of Pachymerinae. Memoirs of the American Entomological Society, 41: 1104.

SCARIOT, A., 1998, Seed dispersal and predation of the palm Acrocomia aculeata. Principes, 42(1): 5-8.

SCARIOT, A. O., LLERAS, E. \& HAY, J. D., 1991, Reproductive biology of the palm Acrocomia aculeata in Central Brazil. Biotropica, 23(1): 12-22.

SCARIOT, A. O., LLERAS, E. \& HAY, J. D., 1995, Flowe-ring and fruiting phenologies of the palm Acrocomia aculeata: patterns and consequences. Biotropica, 27(2): 168-173.

SIEMENS, D. H. \& JOHNSON, C. D., 1992, Density-dependent egg parasitism as a determinant of clutch size in bruchid beetles (Coleoptera - Bruchidae). Environmental Entomology, 21(3): 610-619.

SIEMENS, D. H. \& JOHNSON, C. D., 1996, Bruchid ovoposition patterns beneath guanacaste trees (Mimosacea) in Venezuela. Probable consequences of extinct dispersers. Biotropica, 28(1): 96-104. 
SILVA, P., 1989, Bruquídeos associados às sementes de palmeiras na Bahia, Brasil (Coleoptera: Bruchidae). Anais da Sociedade Entomológica do Brasil, 18: 155-168.

TRAVESET, A., 1990, Bruchid egg mortality caused by ants and abiotic factors in Acacia farnesiana (L) Wild. Ecological Entomology, 15: 463-467.

TRAVESET, A., 1991, Pre-dispersal seed predation in central american Acacia farnesiana: factors affecting the abundance of co-occurring bruchid beetles. Oecologia, 87: 570-576.
WILSON, D. E. \& JANZEN, D. H., 1972, Predation on Scheelea palm seeds by bruchid beetles: seed density and distance from the parent palm. Ecology, 53: 954959.

WRIGHT, S. J., 1990, Cumulative satiation of a seed predator over the fruit season of its host. Oikos, 58(3): $\quad 272-276$. 